\title{
Characterization of the Undrained Shear Strength of Expansive Soils of High Water Content
}

\author{
Zheng Su ${ }^{1,2}$, Daokun $\mathrm{Qi}^{3}$, Xinju Guo ${ }^{3}$, Xiaojuan $\mathrm{Xi}^{3}$ and Liang Zhang ${ }^{3}$ \\ ${ }^{1}$ Department of Geotechnical Engineering, Tongji University, Shanghai 200092, China; \\ ${ }^{2}$ Key Laboratory of Geotechnical and Underground Engineering of Ministry of Education, Tongji University, Shanghai 200092, China; \\ ${ }^{3}$ State Grid Henan Economic Research Institute, Zhengzhou 450052, China
}

\begin{abstract}
In recent years, engineering constructions increase rapidly in western and central areas of China, where expansive soil widely distributes. Since expansive soil is sensitive to water content, the characterization of its shear strength should be carefully conducted. For simplicity and ease of use, the Mohr-Coulomb criterion is often adopted to describe the shear strength of expansive soil. In this paper, the physical meaning of the cohesion and frictional strength of expansive soil are explained, and the variations of the strength parameters with water content are investigated. By fitting to the experimental results from direct shear test and triaxial tests, the changing characteristics of cohesion and friction angle with water content are obtained.
\end{abstract}

\section{Introduction}

Expansive soil widely distributes in the western and central China. Due to the season changes and temperature variation, the water content changes often. The mechanical behavior, i.e. shear strength and deformation characteristics, is highly affected by its water content. The shear strength increases with the shrinkage and decreases with the swelling effect. Since the increasing construction in expansive soil area, there is a great engineering demand on studying the shear strength of unsaturated expansive soil.

The influence of the water content on the shear strength of granular material has been studied experimentally and theoretically. By using X-ray microtomography, Scheel et al. [1] studied the influence of liquid content on the mechanical properties of glass beads; the findings provide a profound understanding on the wet granular material, including soil. Lu et al. [2] studied this problem in silty sand $(50-200 \mu \mathrm{m})$, fine sand $(80-400 \mu \mathrm{m})$, and medium sand $(200-900 \mu \mathrm{m})$, and found that the results are sensitive to particle size. Results of silty sand showed that the tensile strength increases dramatically to a peak and then decreases gradually with the increase in the saturation. Based on the direct shear tests and 3D molecular dynamic simulation of wet sand and glass beads with diameter of $0.1-1 \mathrm{~mm}$, Richefeu et al. [3] found that with the gradual increase in the water content, the cohesion of wet granular materials increases firstly and then tends to be unchanged, while the friction angle is irrespective of water content. Mani et al.[4] proposed a model to study the redistribution process of liquid in unsaturated granular material in plane shear; results showed that the shear rate profile would affect the liquid migration pattern. Tang et al. [5] investigated the influence of water content and dry density of compacted clay soil on its tensile strength, a peak value of the tensile strength characteristic curve (TSCC) was observed at the critical water content around $11.5 \%$. Based on direct shear tests, Elkady and Abbas [6] studied the influence of two loading paths on the drained strength behavior of expansive soil of the northeast region of Saudi, Arabia; the loading path was shown to affect the strength parameters slightly. Wu and Wang [7] conducted direct shear tests and swelling tests on undisturbed expansive soil in Yanji Basien, and the influence of water content on strength parameters and swelling pressure was obtained; the strength parameters decrease with water content. $\mathrm{H}$. Louati [8] studied the influence of particle size and saturation on shear behavior of partially wet granular material. It was found that shear strength increases for smaller particles and increases with liquid up to a critical value and then decrease.

Based on soil mechanics and theoretical analysis, this paper characterizes the shear strength of expansive soil. The first part is the description of Mohr-Coulomb criterion and the physical explanation of the strength parameter. The second part is the calibration of the criterion by experiments; the existing tests and consolidated undrained traxial tests were used. The varying characteristics of cohesion and friction angle with the water content were clear shown.

\section{The shear strength of unsaturated soil}

The Mohr-Coulomb criterion has been widely used in 
describing the shear strength of soils. The stress used in the criterion can be effective stress or total stress; the effective stress can be calculated by the Terzaghi's principle in fully saturated soil. Since the expansive soil is often unsaturated and the pore water pressure cannot be easily obtained in engineering filed, the criterion is described by total stress for simplicity

$$
\tau=c_{\text {total }}+\sigma * \tan \varphi_{\text {total }}
$$

where $c_{\text {total }}$ and $\varphi_{\text {total }}$ are the equivalent cohesion and friction angle.

The cohesion is caused by the inter-particle physicochemical forces, i.e. van der Waals attraction, electrical double layer repulsion or attraction, cementation due to solute precipitation, and capillary stress; the capillary stress can be induced by the negative pore pressure or the surface tension of liquid [2]. The first two components are important parts for fine grained soils especially for clay [9], the third component is important for some soil, i.e. loess, and the capillary stress are significant for unsaturated soil. The equivalent cohesion $c_{\text {total }}$ can be described as

$c_{\text {total }}=c_{v a}+c_{e a}+c_{c e}+c_{c p}+c_{c t}$

where $c_{v a}$ is van der Waals attraction, $c_{e a}$ is electrical double layer repulsion or attraction, $c_{c e}$ is cementation due to solute precipitation, $c_{c p}$ is capillary stress due to the negative pore pressure, $c_{c t}$ is capillary stress due to the surface tension of liquid.

Since the water contend affects the interaction between the water and particles, the schematic description of the particle-water-gas system in microscopic point of view is shown in Figure. 1. The capillary attraction is significant when the soil contains very low water content, and the reason is that the water concentrates among the small voids and forms capillary bridges under this condition (as shown in Figure.1-(b)). The macroscopic capillary attraction or tension strength is relatively small because of the interconnectivity of the voids in soil. With the increase in saturation, more small voids in soil are filled by water and connected with each other to be capillary clusters (as shown in Figure.1-(c)). As a result, the macroscopical capillary attraction is higher under this condition. Nevertheless, the macroscopic capillary attraction decreases when the saturation goes higher for the voids remained empty in soil under this condition is the macro-voids, which contributes to a relatively small capillary attraction. Finally, the capillary attraction goes to zero when the soil is saturated.

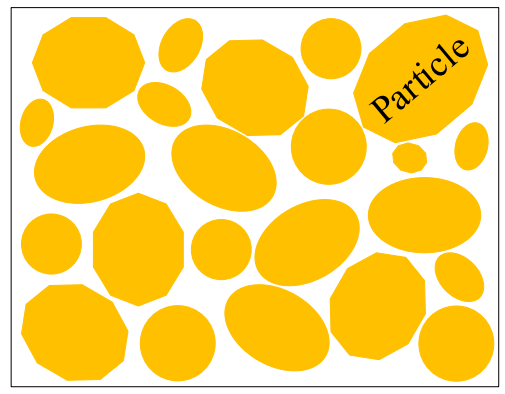

(a) dry

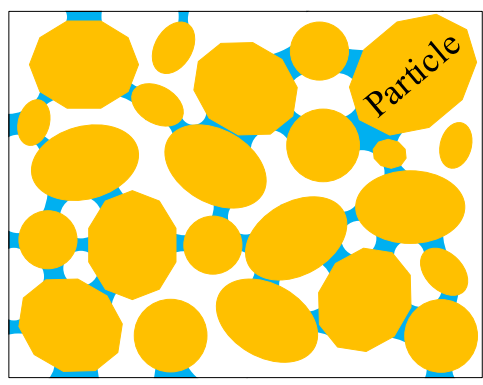

(b) low saturation

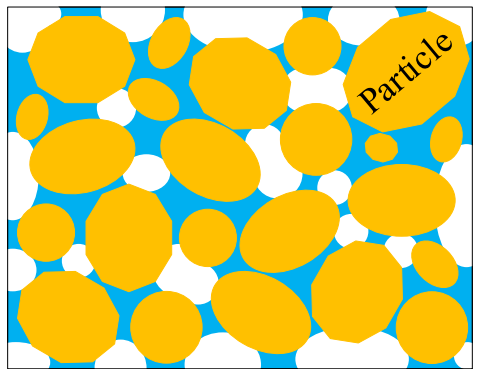

(c) high saturation

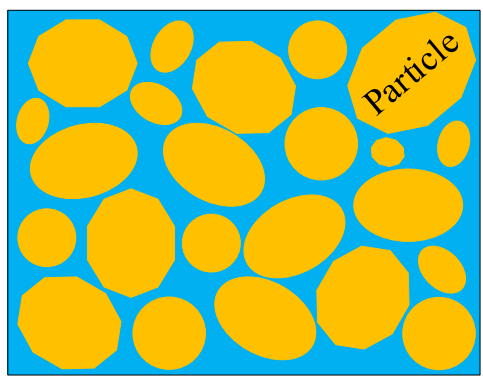

(d) fully saturated

Figure.1. Schematic description of unsaturated soil.

Since the friction angle $\varphi_{\text {total }}$ comes from the friction between particles, it will be inevitably affected by water content. The existence of water between particles decreases the sliding friction for the liquid lubrication. The equivalent friction angle $\varphi_{\text {total }}$ can be defined as

$\varphi_{\text {total }}=\varphi_{\text {fr }}+\varphi_{o c}$

where $\varphi_{f r}$ and $\varphi_{o c}$ are components induced by the sliding friction and interlocking between particles. It is apparent that $\varphi_{f r}$ is sensitive to water content due to the lubrication effect.

Based on the theory mentioned above, the influence of water content on the strength parameters of soil is described in table 1 from micro perspective.

Table 1 Influence of water content on strength parameters

\begin{tabular}{|c|c|c|}
\hline $\begin{array}{l}\text { Water } \\
\text { content }\end{array}$ & Cohesion & Friction angle \\
\hline $\begin{array}{c}\text { Low } \\
\text { water } \\
\text { content }\end{array}$ & $\begin{array}{l}\text { The capillary stress } \\
\text { would increase } \\
\text { when water content } \\
\text { increases from zero } \\
\text { to a lower value. As }\end{array}$ & $\begin{array}{l}\text { Both the sliding } \\
\text { friction and } \\
\text { interlocking friction } \\
\text { are barely affected by } \\
\text { variation of water }\end{array}$ \\
\hline
\end{tabular}




\begin{tabular}{|c|c|c|}
\hline $\begin{array}{c}\text { Water } \\
\text { content }\end{array}$ & Cohesion & Friction angle \\
\hline & $\begin{array}{l}\text { a result, cohesion } \\
\text { increases slightly in } \\
\text { the meantime. }\end{array}$ & $\begin{array}{l}\text { content due to the } \\
\text { disconnectivity of the } \\
\text { water in voids between } \\
\text { soil particles. }\end{array}$ \\
\hline $\begin{array}{l}\text { Medial } \\
\text { water } \\
\text { content }\end{array}$ & $\begin{array}{l}\text { The capillary stress } \\
\text { decreases with } \\
\text { water content } \\
\text { increase gradually, } \\
\text { and cohesion } \\
\text { decreases. }\end{array}$ & $\begin{array}{l}\text { The } \varphi_{\text {total }} \text { would } \\
\text { decreases with water } \\
\text { content increases, } \\
\text { because the sliding } \\
\text { friction is affected by } \\
\text { water content } \\
\text { obviously. }\end{array}$ \\
\hline $\begin{array}{c}\text { High } \\
\text { water } \\
\text { content }\end{array}$ & $\begin{array}{l}\text { The capillary stress } \\
\text { decreases to be zero } \\
\text { when the water } \\
\text { content goes to very } \\
\text { high or the soil is } \\
\text { approximate to } \\
\text { saturated. Hence, } \\
\text { the cohesion } \\
\text { decreases further on } \\
\text { this occasion. }\end{array}$ & $\begin{array}{l}\text { The influence of water } \\
\text { content on sliding } \\
\text { friction tends to be } \\
\text { ignorable in high water } \\
\text { content. As a result, } \\
\text { the friction angle } \\
\varphi_{\text {total tends to be }} \\
\text { stable on this occasion. }\end{array}$ \\
\hline
\end{tabular}

Based on the theory mentioned above, the parabolic and metatypic Pearl growth curve formulas were proposed to describe the relationship between water content and the equivalent strength parameters as following:

$$
\begin{gathered}
c_{\text {total }}=m w^{3}+n w^{2}+p w+q \\
\varphi_{\text {total }}=\frac{1}{a+b * e^{(w-d)}}+k
\end{gathered}
$$

Where, $m, n, p, q, a, b, d, k$ are fitting parameters, and $q>0, a>0, b>0, \omega_{\text {sat }}>d>0, k>0 . w$ is water content.

\section{Calibration by experimental results}

\subsection{Existing experiments}

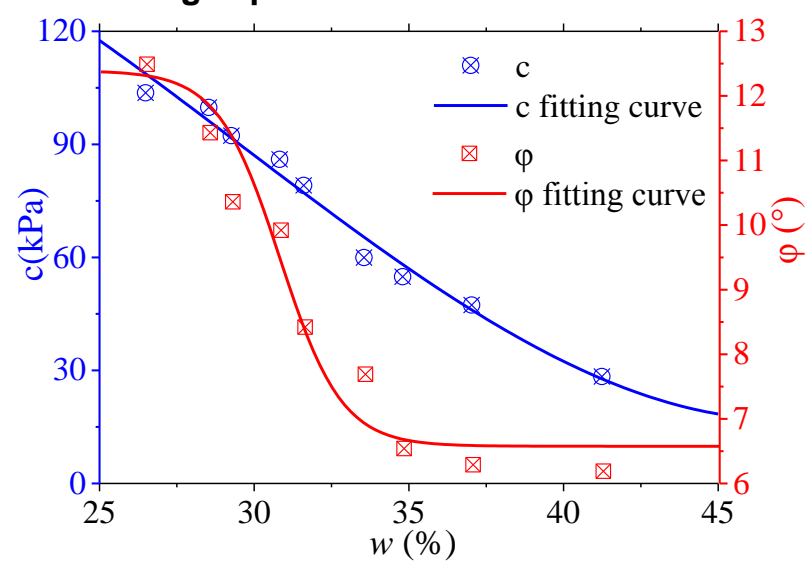

(a) Yichang expansive soil (after Kong et al. (2000)[10])

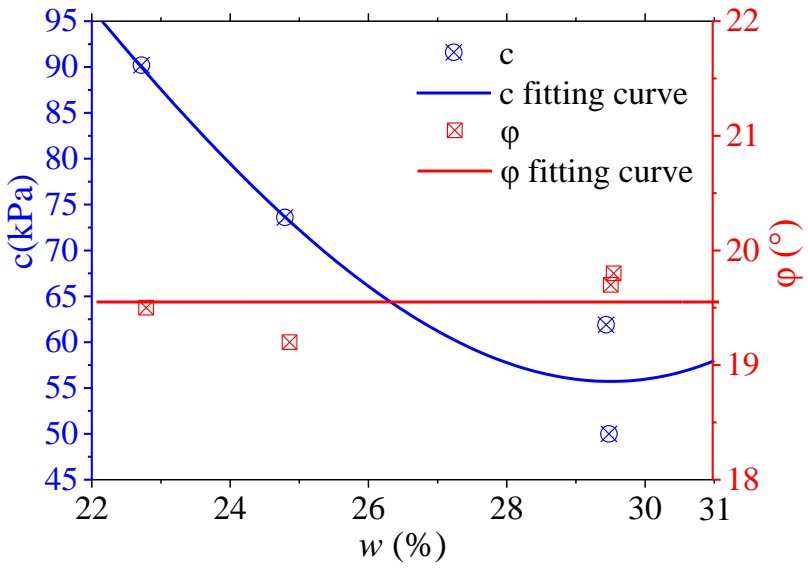

(b) Guangxi expansive soil (after Miao et al. (2007)[11])

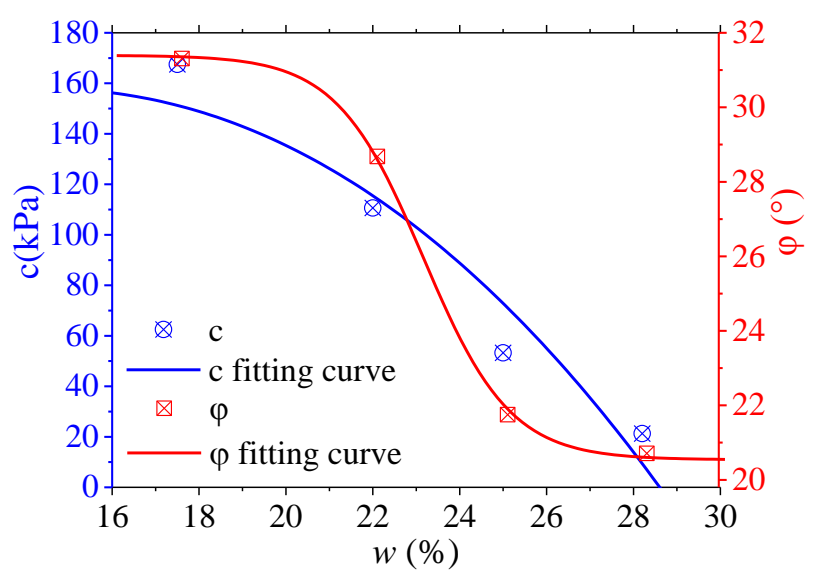

(c) Hunchun expansive soil (after Wu et al. (2017)[7])

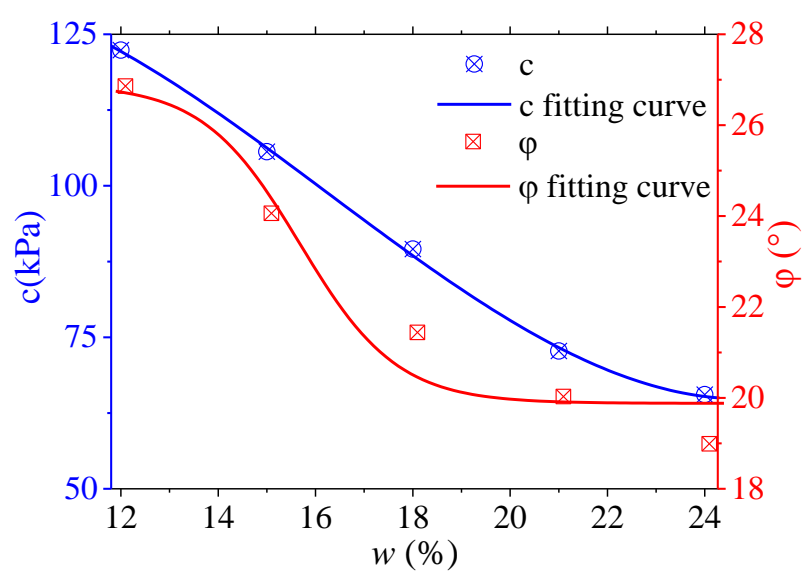

(d) Hanzhong expansive soil (after Jia et al. (2014)[12]) 


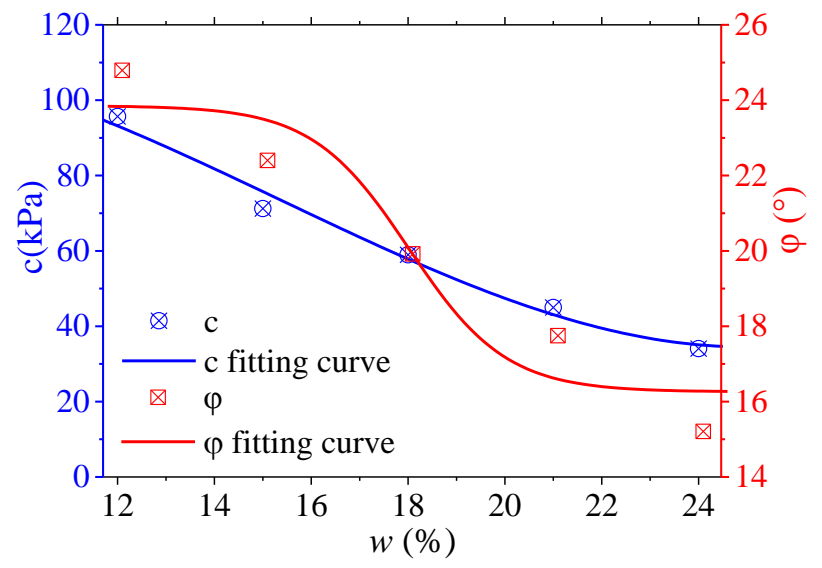

(e) Ankang expansive soil (after Jia et al. (2014)[12])

Figure.2. Strength parameters of expansive soil.

Table 2 Tests of expansive in different areas

\begin{tabular}{|c|c|c|c|}
\hline $\begin{array}{c}\text { Type of } \\
\text { expansive } \\
\text { soil } \\
\end{array}$ & Sample type & Test method & $\begin{array}{l}\text { Water } \\
\text { content }\end{array}$ \\
\hline $\begin{array}{l}\text { Yichang } \\
\text { expansive } \\
\text { soil [10] }\end{array}$ & $\begin{array}{l}\text { Remoulded } \\
\text { sample }\end{array}$ & $\begin{array}{c}\text { Direct shear } \\
\text { test }\end{array}$ & $\begin{array}{c}\text { Medial-high } \\
\text { water content }\end{array}$ \\
\hline $\begin{array}{c}\text { Guangxi } \\
\text { expansive } \\
\text { soil [11] }\end{array}$ & $\begin{array}{l}\text { Remoulded } \\
\text { sample }\end{array}$ & $\begin{array}{c}\text { Triaxial } \\
\text { consolidated } \\
\text { drained test }\end{array}$ & $\begin{array}{c}\text { High water } \\
\text { content }\end{array}$ \\
\hline $\begin{array}{l}\text { Hunchun } \\
\text { expansive } \\
\text { soil[7] }\end{array}$ & $\begin{array}{l}\text { Undisturbed } \\
\text { sample }\end{array}$ & $\begin{array}{c}\text { Direct shear } \\
\text { test }\end{array}$ & $\begin{array}{c}\text { Medial-high } \\
\text { water content }\end{array}$ \\
\hline $\begin{array}{l}\text { Hanzhong } \\
\text { expansive } \\
\text { soil[12] }\end{array}$ & $\begin{array}{l}\text { Remoulded } \\
\text { sample }\end{array}$ & $\begin{array}{c}\text { Triaxial } \\
\text { consolidated } \\
\text { undrained } \\
\text { test }\end{array}$ & $\begin{array}{c}\text { Medial-high } \\
\text { water content }\end{array}$ \\
\hline $\begin{array}{l}\text { Ankang } \\
\text { expansive } \\
\text { soil[12] }\end{array}$ & $\begin{array}{l}\text { Remoulded } \\
\text { sample }\end{array}$ & $\begin{array}{c}\text { Triaxial } \\
\text { consolidated } \\
\text { undrained } \\
\text { test }\end{array}$ & $\begin{array}{l}\text { Medial-high } \\
\text { water content }\end{array}$ \\
\hline
\end{tabular}

To validate the above formulas, three experimental results of the shear strength of partially saturated expansive soil were adopted. The first one is the direct shear test on the expansive soil in Yichang, Hubei [10]. The obtained shear strength is shown in Figure.2(a); with the increase in water content, $\varphi$ decreases firstly and then tends to be a constant, and the cohesion monotonically decreases from $103.67 \mathrm{kPa}$ to $28.38 \mathrm{kPa}$. The strength parameters decrease with water content similarly. The second one is the triaxial tests conducted on Guangxi expansive soil [11]. The obtained cohesion and friction angle under different water content conditions are plotted in Figure.2(b). The cohesion decreases approximate linearly with the saturation degree, however, the friction angle remains constant (around $19^{\circ}$ ). The third one is the direct shear test on the expansive soil in Hunchun, Jilin[7]. The fourth and fifth are Hanzhong and Ankang expansive soil in Sichuan respectively.Similar pattern can be found in
Figure.2(a), (b), (c), (d) and (e), the experimental results match the theory when the water content of the expansive soil is high.

\subsection{Consolidated undrained triaxial tests on Nanyang expansive soil}

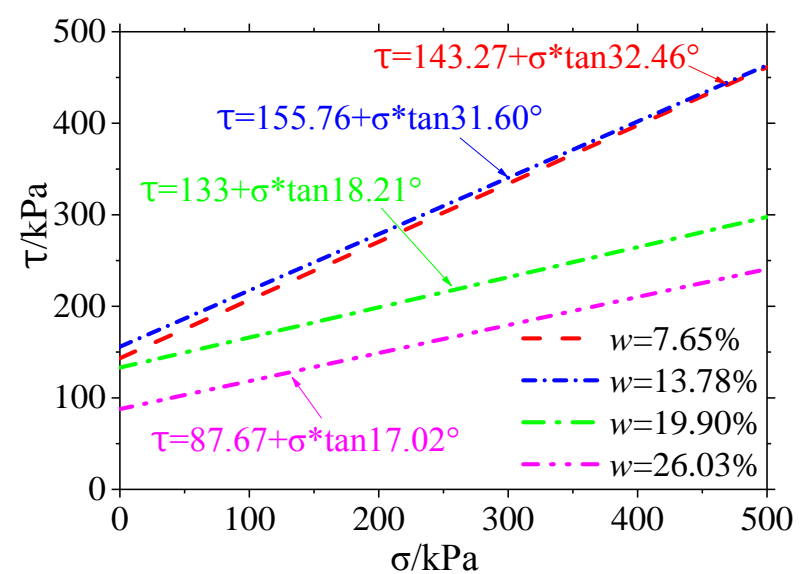

(a) Strength envelope lines



(b) Strength parameters

Figure.3. Failure envelope lines and strength parameters of Nanyang expansive soil.

To further validate the propose failure criterion, a series of consolidated drained triaxial tests were conducted. Soil samples were remodeled by using the expansive soil from Nanyang city, Henan province. The experiments were conducted on the GDS controlled stress path triaxial instrument at Tongji University. The air in the samples was allowed to be exhausted and the specimen was kept undrained. The confining pressures were 50, 100, and 200 $\mathrm{kPa}$ and the water content of the sample were $\omega=7.65 \%$, $13.78 \%, 19.90 \%, 26.03 \%$ (with $\mathrm{Sr}=25 \%, 45 \%, 65 \%, 85 \%$ respectively). According to the stress-strain relationship from the test results, the peak shear stress under different confining stress and water content can be obtained. As shown in Figure. 3(a), the strength envelope lines were obtained by fitting the Eq. (1) against the experimental data. The cohesion and friction angle of the expansive soil with different initial water content is shown in Figure. 3(b). With the increase in the water content, the cohesion and friction angle show decreasing trends as a whole. Besides, fitting parameters of the six kinds of expansive soil are listed in table 3 . 
Table 3 fitting parameters of different expansive soil

\begin{tabular}{ccccccc}
\hline & $\begin{array}{c}\text { Nanya } \\
\text { ng }\end{array}$ & Yichang & $\begin{array}{c}\text { Guan } \\
\text { gxi }\end{array}$ & $\begin{array}{c}\text { Hunc } \\
\text { hun }\end{array}$ & $\begin{array}{c}\text { Hanzh } \\
\text { ong }\end{array}$ & $\begin{array}{c}\text { Anka } \\
\text { ng }\end{array}$ \\
\hline $\mathrm{m}$ & -0.001 & 0.0068 & 0.031 & -0.007 & 0.028 & 0.022 \\
$\mathrm{n}$ & -0.342 & -0.603 & -1.807 & -0.408 & -1.346 & -1.032 \\
$\mathrm{p}$ & 8.39 & 11.61 & 25.08 & 15.93 & 15.87 & 9.79 \\
$\mathrm{q}$ & 105.25 & 98.00 & 86.65 & 32.87 & 77.83 & 85.65 \\
$\mathrm{a}$ & 0.062 & 0.172 & 0.317 & 0.092 & 0.142 & 0.132 \\
$\mathrm{~b}$ & 35.46 & $2.52 * 10^{-5}$ & 0.95 & 0.039 & 0.197 & 0.096 \\
$\mathrm{~d}$ & 23.33 & 21.95 & 0.034 & 22.2 & 15.91 & 17.61 \\
$\mathrm{k}$ & 16.13 & 6.576 & 19.55 & 20.54 & 19.88 & 16.26 \\
\hline
\end{tabular}

\section{Summary}

The Mohr-Coulomb criterion was adapted to describe the undrained shear strength of unsaturated expansive soil, and the cohesion and friction angle in total stress state were obtained. The physical meaning of cohesion and frictional strength were interpreted microscopically. Existing experiments on unsaturated expansive soil were adopted to study variations of cohesion and friction angle with water content. Triaxial tests of unsaturated expansive soil in Nanyang with were conducted, and the obtained cohesion shows a peak value in the cohesion-saturation curve, while the friction angle doesn't. However, the shear strength characteristic of expansive soil at very low saturation and the application of the theory proposed in the paper for expansive soil in other places in the world are not yet studied in this paper, and it deserves further study.

\section{Acknowledgement}

The financial support by the State Grid Corporation of China (Grant No. 5217L0160001) and the Fundamental Research Funds for the Central Universities (0200219221) is gratefully acknowledged.

\section{Reference}

1. M. Scheel, R. Seemann, M. Brinkmann,et al. Morphological clues to wet granular pile stability. Nature MaterialsNature Materials,(2008), 7(3):189-193.

2. Ning Lu, Bailin Wu, Chee P. Tan. Tensile Strength Characteristics of Unsaturated Sands. Journal of Geotechnical and Geoenvironmental Engineering,(2007), 133(2).

3. V. Richefeu, M. Sa Amp, Iuml. Shear strength properties of wet granular materials. Physical Review E,(2006), 73:51304.

4. R. Mani, D. Kadau, H. J. Herrmann. Liquid migration in sheared unsaturated granular media. Granular Matter,(2012), 15(4):447-454.

5. Chao-Sheng Tang, Xiang-Jun Pei, De-Yin Wang,et al. Tensile Strength of Compacted Clayey Soil. Journal of Geotechnical and Geoenvironmental Engineering,(2015), 141(4):4014122.
6. T. Y. Elkady, M. F. Abbas. Shear Strength Behavior of Highly Expansive Soil. GeoCongress 2012: State of the Art and Practice in Geotechnical Engineering,( 2012):2532-2541.

7. Xiong Wu, Zhuo-ran Wang. The relationship between the swelling pressure and shear strength of unsaturated soil: the Yanji Basin as a case study. Arabian Journal of GeosciencesArabian Journal of Geosciences,(2017), 10(15).

8. H. Louati, D. Oulahna, A. D. Ryck. Effect of the particle size and the liquid content on the shear behaviour of wet granular material. Powder Technology,(2017), 315:398-409.

9. J. P. K. Seville, C. D. Willett, P. C. Knight Interparticle forces in fluidisation: a review. Powder Technology,(2000), 113(3):261-268.

10. Ling-wei Kong, Luo-rong Tan. Study on shear strength and swelling- shrinkage characteristic of compacted expansive soil. Unsaturated Soils For Asia,(2000):515-519.

11. Linchang Miao, Sandra L. Houston, Ying Cui,et al. Relationship between soil structure and mechanical behavior for an expansive unsaturated clay. Canadian Geotechnical JournalCanadian Geotechnical Journal,(2007), 44(2):126-137.

12. Wencong, Jia. Experimentle Study on the Strength and Deformation Characteristics of Unsaturated expansive soil. Master's thesis, Northwest Agriculture \& Forestry University. Yangling Shaanxi, China. (2014) (in Chinese) 